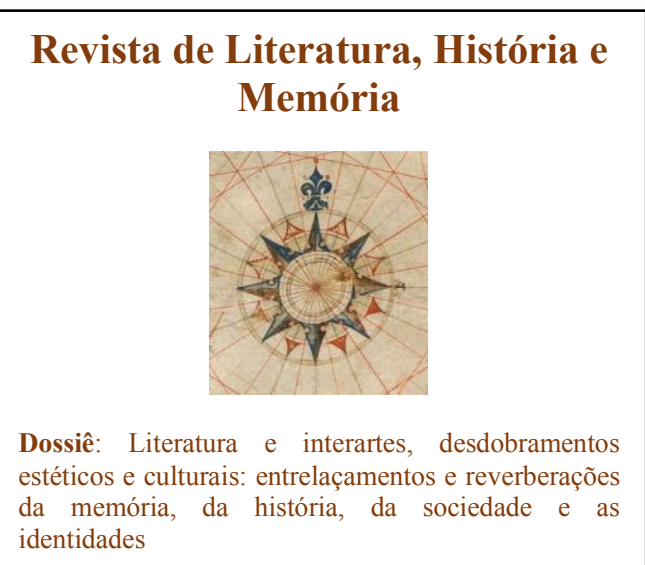

ISSN 1983-1498

VOL. 16 - $\mathbf{N}^{0} 28$ - 2020

U N I O E S T E / CA S C A V E L - p. 46-68

\section{AS REINVENÇÕES LITERÁRIAS DA HISTÓRIA E DA MEMÓRIA: AS IMPOSSIBILIDADES DO MITO FUNDACIONAL BRASILEIRO EM DESMUNDO, DE ANA MIRANDA ${ }^{1}$}

\author{
The literary reinvention of history and memory: the \\ impossibilities of the brazilian foundational myth in \\ Desmundo by Ana Miranda
}

Mônica Naiara Pereira da Silva Santos ${ }^{2}$

RESUMO: Objetiva-se, por meio deste artigo, analisar o processo de (re)construção do mito fundacional no romance Desmundo (1996), da escritora cearense Ana Miranda. Para tanto, apresenta-se, a título de introdução ao debate, algumas considerações essenciais à discussão, como o conceito de nação (RENAN, 1997; ANDERSON, 2008; BHABHA, 1997;

1998; SANTOS, 1997) e como este se inscreve no imaginário literário, além do conceito de mito (BARTHES, 2009) e de mito fundacional (CHAUI, 2000). Essas questões são relevantes para que se possa entender os usos e (pré)juízos do mito fundacional na estética literária. Avaliando a narrativa em Desmundo como uma ficção-limite (HELENA, 1993), investiga-se a retomada do mito de origem como "tópico de rasura da origem" (HELENA, 1993), em movimento contrário ao desenvolvido por José de Alencar em Iracema ([1865] 1989), obra que pode ser considerada, neste contexto, "tópico de origem" (HELENA, 1993). Assim, busca-se compreender como a narrativa ficcional contemporânea pode contribuir no debate sobre a narração da nação brasileira.

PALAVRAS-CHAVE: Nação; Mito; Literatura Brasileira; Ficção-limite; Mito Fundacional.

ABSTRACT: This article aims at analyzing the process of reconstruction of the foundational myth in Desmundo (1996) by the Ceara-born writer Ana Miranda. In order of doing that, it is presented, as an introduction to the debate, some points that are essential to the discussion, such as: concept of nation (RENAN, 1997; ANDERSON, 2008; BHABHA, 1997; 1998; SANTOS, 1997) and how it insert itself in the literary imaginary, besides the concept of myth (BARTHES, 2009) and foundational myth (CHAUI, 2000). This issues are essential to the comprehension of the uses and losses of the literary aesthetic. By evaluating the narrative in Desmundo as a limit-fiction (HELENA, 1993), it is sought the retaken of the origin myth as "topic of erasure of origin" (HELENA, 1993), in an opposite movement to that by Jose de Alencar in Iracema ([1865] 1989), a work that might be taken, in this context, as "topic of origin" (HELENA, 1993). Therefore, it is attempted to comprehend how the contemporary fictional narratives can contribute on the discussion of the Brazilian nation's narration.

KEYWORDS: Nation; Myth; The Brazilian Literature; Limit-Fiction; Foundational Myth.

\footnotetext{
${ }^{1}$ As discussões aqui apresentadas foram desenvolvidas na dissertação de mestrado intitulada Cenários históricoliterários de uma nação na prosa de Ana Miranda, defendida em 2013.

${ }^{2}$ Mestra em Estudos Literários (PROGEL/UEFS), Doutoranda em Literatura e Cultura (PPGLitCult/UFBA). Atualmente, pesquisa as configurações da violência sistêmica em escritos de mulheres negras na e sobre a diáspora africana.
} 


\section{CONSIDERAÇÕES INICIAIS}

Sobre o existir/viver em comunidade, pesquisadores e ficcionistas experimentam uma constante inquietação: o que torna o meu país uma nação? O que faz de mim parte dessa nação? São preocupações que a historiografia busca responder, sempre auxiliada pela literatura. Muitas histórias literárias tentam suprir as lacunas de nossa narrativa de formação social, no sentido de performatizar a origem e narrar a nação (BHABHA, 1997). E, durante muito tempo, o Romantismo brasileiro deteve a quase exclusividade literária de dizer ficcionalmente como nos constituímos uma nação - a nação brasileira, principalmente por meio da obra nacionalista de José de Alencar.

Mas, passados séculos dessa fase nacionalista romântica, resta-nos, atualmente, questionar sobre esse legado e seus descendentes ficcionais, quanto à narração da nação. Segundo Marilena Chaui (2000, p. 14), a invenção histórica da nação - como Estado-nação - ainda é muito recente, data de, aproximadamente, 1830. Essa ideia de Estado-nação, apesar de muito discutida, permanece envolta em incompletudes e incertezas. Por exemplo, Eric Hobsbawm (2011, p. 10), no prefácio de Nações e nacionalismo desde 1780: programa, mito e realidade, adverte sobre a dificuldade que envolve o tema, afirmando que a questão nacional “[...] é, notoriamente, um tema controverso"; já Benedict Anderson (2008, p. 28), em Comunidades Imaginadas: reflexões sobre a origem e a difusão do nacionalismo, observa que os fatos que dizem respeito ao tema são claros, mas a “[...] explicação deles continua sendo objeto de longa discussão. Nação, nacionalidade, nacionalismo - todos provaram ser de dificílima definição, que dirá de análise. [...] é notável a escassez de teorias plausíveis sobre ele."

Ainda de acordo com Chaui (2000, p. 14-15), a palavra "nação" vem do verbo latino nascor - nascer - e do substantivo derivado desse verbo, natio - nação. O substantivo natio designa o parto de um animal ou de uma ninhada. Por conta desse significado, o substantivo passou também a designar os indivíduos nascidos de uma mesma mãe e, depois de algum tempo, os sujeitos nascidos em um mesmo lugar. No início da Idade Média, a Igreja Romana estabeleceu seu vocabulário latino, e o plural nationes - nações - começou a ser usado para se referir aos pagãos e diferenciá-los do "povo de Deus" - populus Dei. Nesse contexto, nação designava tanto os não cristãos, como os estrangeiros e populações sem um sistema de governo instituído; já "povo" dizia respeito a um grupo de pessoas pertencentes a um sistema institucional de regras e leis comuns.

Assim, constatamos que a busca pelos elementos que constituem, agrupam e 
mantêm unido um povo é um tema recorrente nos estudos de historiadores, antropólogos, sociólogos e literatos, que consideram, para tanto, a importância da língua(s) falada(s), da(s) etnia(s) envolvida(s), da história fundadora, das crenças religiosas, do modelo administrativo etc. Entretanto, nessas investigações, concluem que outros tantos elementos, variáveis de acordo à nação analisada, são importantes na compreensão da ideia de nação, como, por exemplo, o desejo de pertença, o sentimento da/pela pátria - elementos subjetivos, logo, difíceis de qualificar.

Esses elementos comuns citados acima, desde os facilmente enumeráveis como a história, a língua, etnia, religião e governo, assim como os mais difíceis de serem enumerados, como é o caso dos sentimentos da/pela nação, podem ser observados na saga dos hebreus a caminho da "Terra Prometida", a idealizada Canaã, presente no Velho Testamento da Bíblia cristã.

No primeiro livro escrito pelo profeta Moisés, o dos Gênesis, é Abrão quem recebe a promessa que iniciará a saga do povo hebreu: "Sai-te da tua terra, e da tua parentela e da casa de teu pai, para a terra que eu te mostrarei. E far-te-ei uma grande nação, e abençoarte-ei, e engrandecerei o teu nome e $t u$ serás uma benção" (GÊNESIS, 1995, p. 11-12, itálico do texto, negritos meus). A promessa da grande nação estava se cumprindo, até a fome expulsar Abrão de Canaã em direção ao Egito, onde conseguiu prosperar, mas sem nunca deixar de acalentar a lembrança da terra prometida.

Porém, o sofrimento se abate, no Egito, sobre o povo de Deus, por meio das altas taxas imputadas aos hebreus e pela sentença de morte às crianças (do sexo masculino) recém-nascidas das hebreias, entre outros mecanismos de perseguição instituídos pelo rei egípcio. E, de dentro de uma sarça que pegava fogo, o Deus dos hebreus fala e determina a Moisés, que continuará a missão - de guiar o povo - dada inicialmente a Abrão:

[...] Tenho visto atentamente a aflição do meu povo, que está no Egito, e tenho ouvido o seu clamor por causa de seus exatores, porque conheci as suas dores.

Portanto desci para livrá-lo da mão dos egípcios, e para fazê-lo subir daquela terra, a uma terra boa e larga, a uma terra que mana leite e mel (ÊXODO, 1995, p. 63-64, itálico do texto, negritos meus).

Moisés anuncia ao faraó a saída do povo do Egito, após 400 anos ali vividos. A princípio, o faraó resiste, mas, quando, enfim, a retirada é permitida, o povo parte em um êxodo que dura 40 anos. Nessa história o que nos interessa são as mesmas questões que inquietam àqueles que buscam compreender a nação moderna: quais os elementos que 
constituem esse povo como uma nação (a nação de Israel)? O que manteve esse povo unido (ou não) ao longo de tantos anos? Enfim, o que é uma nação?

Essa última questão tornou-se conhecida após ser proposta por Ernest Renan em um ensaio da mesma forma intitulado. Dentre os fatores essenciais na construção de uma nação, ele destaca o esquecimento e o erro histórico, ressaltando que a investigação da história revive acontecimentos violentos já adormecidos na lembrança do povo, e enfatizando que relembrar tais fatos pode ser perigoso para a ideia de nação, ainda que saibamos que a "[...] unidade se faz sempre por meios brutais" (RENAN, 1997, p. 17-18).

Para Renan (1997, p. 20), é o esquecimento e os interesses comuns que unem um povo, por isso afirma que “[...] a essência de uma nação está em que todos os indivíduos tenham muito em comum, e também que todos tenham esquecido muitas coisas." Para Anderson (2008, p. 32), essa assertiva de Renan contém um toque levemente irônico, nem sempre compreendido pelos leitores. Na verdade, o que a afirmativa enfatiza é que o esquecimento é substituído pela imaginação. Um conceito de nação que, portanto, baseia-se em uma abstração.

Assim, constatamos que é essa mesma imaginação que mantém o povo hebreu unido - e em êxodo - por tantos anos, isto é, é a esperança, a imagem da "terra que mana leite e mel", onde não haverá mais sofrimentos nem fome, desde, é claro, que as regras mandamentos, ensinamentos - sejam obedecidas. Como em grande parte dos grupos sociais, as regras são estabelecidas para manter a ideia da unidade, para imaginar-se essa unidade. A imaginação é o primeiro elemento aqui destacado dentre os fatores essenciais na formação e solidificação de uma nação. "Imaginar" e "esquecer" se complementam na difícil tarefa de definir o nacional.

Em crítica ao texto de Renan (1997), Anderson (2008, p. 272-280) afirma que o que mais preocupou o escritor francês foi exatamente a necessidade de esquecer. Anderson comenta que no seu primeiro debate sobre o texto de Renan (em 1983, quando foi publicada a primeira edição do livro Comunidades Imaginadas: reflexões sobre a origem e a difusão do nacionalismo) não percebeu a dimensão crítica da assertiva de Renan. Aparentemente simples e direta, essa afirmativa mostra-se realmente estranha após alguns momentos de reflexão. Ao sugerir que "[...] todo cidadão francês precisa ter esquecido São Bartolomeu, os massacres do Sul no século XIII” (RENAN, 1997, p. 26), ele não considera necessário explicar o que significa "São Bartolomeu” ou "os massacres do Sul no século XIII.” Anderson (2008, p. 273) avalia que Renan não achou “[ [...] nada esquisito esperar que os seus leitores tivessem 'memória' de acontecimentos ocorridos trezentos e seiscentos anos 
antes.” Anderson destaca que “[...] Renan diz aos leitores que estes 'já tinham esquecido’ o que as suas próprias palavras supunham que eles lembrariam naturalmente" (ANDERSON, 2008, p. 273). Esse paradoxo reflete, segundo Benedict Anderson, a campanha historiográfica sistemática desenvolvida pelo Estado, principalmente por meio do sistema público de ensino, para lembrar a juventude francesa de uma série de tragédias passadas que, então, começavam a ser inscritas como "história de família".

Sob essa ótica, Le Goff (2003, p. 419-471) também afirma o valor da memória, que considera ser um elemento essencial da "identidade", tanto individual quanto coletiva. Assim como Anderson (2008), ele destaca que a memória coletiva é, além de uma conquista, um instrumento e um objeto de poder. Por isso, assegura que tornar-se "[...] senhores da memória e do esquecimento é uma das grandes preocupações das classes, dos grupos, dos indivíduos que dominaram e dominam as sociedades históricas", ressaltando, ainda, que os “[...] esquecimentos e os silêncios da história são reveladores destes mecanismos de manipulação da memória coletiva" (LE GOFF, 2003, p. 422).

Em resumo, esse lembrar opera na margem do duplo termo lembrar/esquecer, ou seja, esquecer singularidades (por exemplo, que a suposta carnificina entre irmãos franceses, na verdade, oculta que os albigenses assassinados falavam o catalão ou provençal) e generalizar o conflito (afirmando ser essa "mais uma história de família", e não uma disputa pela centralização do poder francês). As lacunas geradas pelo esquecimento são preenchidas pela imaginação, com o intuito de completar a linha contínua da história nacional, isso porque a biografia da nação

[...] agarra, à revelia dos índices de mortalidade, aqueles suicídios exemplares, os martírios dolorosos, os assassinatos, as execuções, as guerras e os holocaustos. Mas, para servir à finalidade narrativa, essas mortes violentas precisam ser lembradas/esquecidas como "nossas" mortes (ANDERSON, 2008, p. 280, grifos meus).

Quanto à questão da imaginação, Homi Bhabha (1998, p. 119, grifo do autor), tomando de empréstimo o esquema de Jacques Lacan, afirma que o imaginário

[...] é a transformação que acontece no sujeito durante a fase formativa do espelho, quando ele assume uma imagem distinta que permite a ele postular uma série de equivalências, semelhanças, identidades, entre os objetos do mundo ao seu redor. No entanto, esse posicionamento é em si problemático, pois o sujeito encontra-se ou se reconhece através de uma imagem que é simultaneamente alienante e daí potencialmente fonte de confrontação. Esta é a base da estreita relação entre as duas formas de identificação associadas ao imaginário - o narcisismo e a agressividade. 
São precisamente essas duas formas de identificação que constituem a estratégia dominante do poder colonial exercida em relação ao estereótipo, que, como uma forma de crença múltipla e contraditória, reconhece a diferença e, simultaneamente, a recusa ou mascara. Como a fase do espelho, a completude do estereótipo - sua imagem enquanto identidade - está sempre ameaçada pela falta.

E é por meio desses elementos complementares - esquecimento e imaginação - que Anderson (2008, p. 32-34) delibera sobre a nação moderna, definindo-a como uma “[...] comunidade política imaginada - e imaginada como sendo intrinsecamente limitada e, ao mesmo tempo, soberana." Segundo ele, é imaginada porque os indivíduos de uma nação, por menor que ela seja, jamais estabelecerão contato com todos os seus membros, mas mesmo assim essas pessoas comungam da mesma imagem viva. Assim, a nação é uma comunidade política imaginada não no sentido de falsa, mas de uma construção discursiva (SANTOS, 1997, p. 23).

É limitada porque "[...] possui fronteiras finitas, ainda que elásticas, para além das quais existem outras nações" (ANDERSON, 2008, p. 33); mas é preciso ressaltar que as fronteiras se cruzam, se indeterminam, se interpenetram (SANTOS, 1997, p. 23). Ela é uma comunidade soberana graças ao período de nascimento do conceito - durante o Iluminismo e a Revolução Francesa, ambos responsáveis pela destruição da legitimidade do reino dinástico, hierárquico e de ordenação divina (ANDERSON, 2008, p. 34).

Por fim, a nação é imaginada como uma comunidade por ser concebida como uma rede de amizade, "camaradagem", interesses comuns, mesmo diante de todas as disparidades que venham a existir em seu interior. Vale ainda destacar que as comunidades não se diferenciam por meios de critérios baseados em falsidade ou autenticidade, mas " [...] pelo estilo em que são imaginadas" (ANDERSON, 2008, p. 34). No entanto, as fronteiras (visíveis e invisíveis) de uma nação moderna encontram-se nas margens de outra nação, e essas margens introduzem a descontinuidade do "outro", do "diferente" (SANTOS, 1997, p. 23-24).

Assim como o conceito de nação proposto por Ernest Renan (1997), a definição de Anderson (2008, p. 33) também se baseia em uma abstração, isto é, a nação só pode ser possível quando/se imaginada; é, assim, um conceito crítico, questionador, que serve de suporte aos princípios apaziguadores das diferenças de uma sociedade. Nesse sentido, a comunidade dos hebreus é imaginada com base no monoteísmo, na crença de um único Deus e na obediência aos seus dogmas, nesse caso, transmitidos, inicialmente, pela figura humana de Moisés e, após sua morte, por Josué (numa linhagem de sucessão parental). Ao 
se estabelecerem em Canaã, os hebreus mudam o seu sistema de governo parental para um modelo em que são os juízes que comandam a sociedade. Mas, séculos depois, ele cede lugar a uma nova forma de organização político-social: a monarquia. Portanto, é a crença religiosa e a obediência ao líder instituído (seja por sucessão parental, pela escolha de juízes ou monarcas) que modelam o estilo dessa comunidade bíblica.

Esses dois fatores, a crença religiosa e a obediência a um líder instituído, são semelhantes aos sistemas culturais elencados por Anderson (2008, p. 39-51) como precedentes do nacionalismo, ou como as raízes culturais da ideia de nação, a saber: a comunidade religiosa e o reino dinástico, além da mudança na percepção temporal. Considera-os grandes sistemas, que, como uma faca de dois gumes, dão origem ao nacionalismo, mas passam a ser combatidos por esse mesmo nacionalismo.

Segundo esse autor, as comunidades religiosas eram imaginadas essencialmente pelo uso de uma língua e uma escrita sagradas, para tanto considera o período dos grandes impérios orientais e ocidentais. O que mantinha uma comunidade religiosa unida, diferentemente das comunidades imaginadas das nações modernas, era a confiança (no caso das comunidades mais antigas) na sacralidade única de suas línguas. Vale lembrar que, no caso da comunidade religiosa cananeia, é na língua hebraica que são escritos os 10 mandamentos, principal suporte dogmático dessa sociedade, além de todas as leis e estatutos propostos por Moisés (ÊXODO, 1995, p. 84-101). É também essa língua que diferencia, na terra de Canaã, os hebreus dos demais povos, como os filisteus e os midianitas, por exemplo.

No entanto, como explica Anderson (2008, p. 43-47), a "coesão inconsciente" das comunidades imaginadas religiosamente declinou, em ritmo constante, logo após o fim da Idade Média, graças aos dois seguintes fatores, relacionados diretamente à sacralização única da língua: as explorações do mundo não europeu, que modificou as dimensões culturais e geográficas e os conceitos sobre as possíveis formas de vida humana; e o crescente rebaixamento da própria língua sagrada.

A origem dessa crença religiosa, estabelecida por meio dos preceitos e dogmas, transmitida, em seu início, através dos profetas - vozes humanas do Deus cristão -, perdese nas brumas do tempo vazio e homogêneo. Conforme Santos (1997, p. 22), o tempo vazio e homogêneo é

[...] um tempo horizontal no qual a um presente pleno corresponde uma visibilidade eterna e total do passado e uma perspectiva progressiva e progressista do futuro. Nesse tempo, o presente surge sempre como 
forma-mãe, em torno do qual se reúnem e se diferenciam o futuro e o passado. Passado e futuro seriam, assim, meras modificações de um presente essencial.

Graças a essa ideia de tempo homogêneo e vazio torna-se possível conceber a nação como uma narrativa. Para Homi Bhabha (1997, p. 48, grifos meus), as "[...] origens das nações, assim como das narrativas, perdem-se nos mitos do tempo e apenas na memória seus horizontes se realizam plenamente.” Portanto, “[...] é a partir das tradições do pensamento político e da linguagem literária que a nação surge, no Ocidente, como uma poderosa idéia [sic] histórica" (BHABHA, 1997, p. 48, grifos meus). Logo, os mitos desempenham papel fundamental nesse processo de narrar a nação.

Nessa perspectiva, para responder à questão sobre como é contada a narrativa da cultura nacional, Stuart Hall elenca várias estratégias discursivas que servem ao propósito de escrever a história da nação. Dentre essas estratégias usadas para narrar a comunidade imaginada, destaca-se a do "mito fundacional", que serve para caracterizar/representar nacionalmente a origem de uma nação. O mito fundacional é uma estória

[...] que localiza a origem da nação, do povo e de seu caráter nacional num passado tão distante que eles se perdem nas brumas [...] de um tempo 'mítico'. [...] [Assim, os mitos] fornecem uma narrativa através da qual uma estória alternativa ou uma contranarrativa [...] pode ser construída (HALL, 2003, p. 54-55).

Novas nações, segundo Hall (2003), são fundadas sobre mitos. Segundo Roland Barthes (2009, p. 199-200), o mito é, atualmente, uma fala, mas não uma fala qualquer. Ele é um sistema de comunicação, uma mensagem, um modo de significação, uma forma; logo, não pode ser um objeto, conceito ou ideia. Nesse contexto, tudo pode constituir-se como mito, desde que seja suscetível do julgamento discursivo. É, inclusive, concebível, segundo o autor, que haja mitos muito antigos, mas não eternos, uma vez que é a História que transforma o real em discurso, que comanda a vida e a morte da linguagem mítica.

Se a História, que é mutável e, hodiernamente, ainda mais consciente de seu processo pseudocontínuo de escrita historiográfica, é que comanda o início e o fim da fala mítica, deste modo, é evidente que as matérias-primas do mito - tanto as representativas quanto as gráficas - pressupõem uma consciência significante (BARTHES, 2009, p. 201203). Assim, apesar de se constituir no esquema tridimensional da linguagem (significante, significado e referente), o mito é um sistema particular que se constrói a partir de uma cadeia semiológica que já existe antes dele (BARTHES, 2009, p. 205). 
Barthes ainda afirma que existem dois sistemas semiológicos no mito, e um deles está deslocado em relação ao outro: o primeiro, que ele chama de linguagem-objeto, é a língua (o mito se serve dessa linguagem para construir seu próprio sistema); e o segundo, chamado de metalinguagem, é o próprio mito (é metalinguagem porque já é uma segunda língua, na qual se fala da primeira) (BARTHES, 2009, p. 206). Considerando-o segunda língua e histórico, o autor enfatiza que não existe fixidez na linguagem mítica; depois de construída, ela pode reconstruir-se, alterar-se, desfazer-se e até mesmo desaparecer completamente. Segundo Barthes (2009, p. 212), é por conta desse seu caráter histórico que surge a necessidade de renovação do mito, o neologismo.

Essa mutabilidade do mito pode ser bastante favorável ao processo de narração da nação e para sua tentativa de apaziguar as tensões entre o que deve/como deve e não deve ser de conhecimento futuro, por exemplo, por meio do mito de fundação. Marilena Chaui (2000, p. 9) analisa a questão do mito fundador considerando-o tanto em sua acepção etimológica (ou seja, como uma narração pública de feitos lendários de uma comunidade) quanto antropológica (uma narrativa que se apresenta como a solução imaginária para conciliar tensões, conflitos e contradições difíceis de serem resolvidas no plano da realidade), mas também psicanalítica (como um impulso à repetição de algo imaginário, que bloqueia a percepção da realidade).

Chaui (2000, p. 9) explica, ainda, que o mito é fundador porque impõe um “[...] vínculo interno com o passado como origem, isto é, com um passado que não cessa nunca, que se conserva perenemente presente e, por isso mesmo, não permite o trabalho da diferença temporal e da compreensão do presente enquanto tal." Ele se atualiza, portanto, através dos neologismos, conforme afirma Barthes.

\section{DESMUNDO E A IMPLOSÃO DO MITO DE ORIGEM}

Podemos considerar o romance Desmundo, escrito pela cearense Ana Miranda, uma "ficção-limite", segundo definição dada por Lucia Helena (1993, p. 80) a algumas narrativas que se definem pela forma como nelas transbordam os parâmetros consensuais da tradicional estética romanesca, trabalhando com a articulação do mítico, do histórico e do ficcional. Esse tipo de ficção procura examinar o mito da fundação da cultura nacional, tanto para implantá-lo quanto para questioná-lo. Em Desmundo (MIRANDA, 1996), notamos que a fala mítica é analisada, questionada, descentralizada, ou melhor, as novas configurações dadas ao mito de origem questionam e põem em xeque àquelas outras 
histórias fundacionais - aqueles mitos que promovem a pseudodemocracia racial, na enunciação de uma dialética da miscigenação das raças.

Segundo Linda Hutcheon (1991, p. 222), os romances pós-modernos questionam os pressupostos do passado com referência à redação de romances, assim como já foram contestados os pressupostos do século XIX sobre a redação da história narrativa. Para ela, nem um dos dois atos pode ser considerado neutro, mesmo porque os dois questionam a prioridade do sujeito. Isso porque é na diferença, na descentralização que a identidade surge como um problema. Para Zygmunt Bauman (2005, p. 21-22), a identidade só pode ser revelada aos indivíduos como algo a ser inventado e não descoberto, como um objetivo, como um processo que começa a partir de um ponto escolhido. Esse ponto pode ser a identificação com um lugar - a comunidade. Segundo Santos (1997, p. 28-29), a identidade se estabelece em um espaço entre o narrar e o ser narrado. Já Guibernau (1997, p. 82-83) ressalta que a procura da identidade inclui a necessidade de pertencer a uma comunidade.

Em síntese, é a linguagem que nos constitui como uma nação, é a linguagem que hoje faz de nós - para o outro e para muitos de nós - a nação do futebol, do carnaval e do samba, ainda que os dois primeiros não tenham surgido em nosso território. Por essa razão é tão relevante analisar os mitos (re)inventados ficcionalmente, uma vez que eles promovem uma imagem do nacional, uma identidade nacional; eles propagam uma ideia de nação que precisa ser problematizada, principalmente quando não considera todas as violências suplantadas/esquecidas pela imaginação (BHABHA, 1997; 1998; RENAN, 1997; ANDERSON, 2008).

A ficção-limite Desmundo (MIRANDA, 1996) está no seguimento de narrativas que promovem um retorno ao passado nacional, aos primórdios da invasão e colonização. Nele, o espaço e o tempo são sugeridos pela caracterização das personagens, pelo desenho do contexto social, pelos conflitos entre os sujeitos, pelo retrato das necessidades e desejos dos indivíduos, mas sem estarem encerrados em datas. Na verdade, a única data marcada na obra - 1552 - está na epígrafe do romance. Temos, assim, a alusão a um relevante ano para a história do Brasil Colonial, que, longe de datar a trama ficcional, enuncia questões para além do contexto quinhentista. Essa ficção reconstrói memórias com o olhar do presente, com a necessidade hodierna de entender as origens, compreendendo, portanto, a História como um diálogo recorrente entre presente e passado, numa projeção crítica de futuro.

Conforme Linda Hutcheon (1991, p. 150), Umberto Eco afirma que existem três maneiras de narrar o passado: por meio da fábula, da estória heroica e do romance histórico. Para ele, o romance histórico, além de identificar no passado as causas para o que aconteceu 
depois, investiga o processo que leva aos efeitos dessas causas (HUTCHEON, 1991, p. 150). Considerando essa pressuposição de Eco, Hutcheon (1991, p. 150) acrescenta uma quarta maneira de narrar o passado, que ela chama de metaficção historiográfica, e não apenas ficção histórica. A diferença reside na "intensa autoconsciência" em relação à maneira como o processo de escrita é realizado. Ela ainda enfatiza que o que "[...] a arte e a teoria pósmodernistas têm em comum é uma consciência das práticas e instituições sociais que as modelam. O contexto é tudo" (HUTCHEON, 1991, p. 80). Observamos essa autoconsciência do processo de criação literária na prosa de Ana Miranda. Autoconsciência em relação à estilística e à temática (híbrida, incompleta e interdiscursiva) do gênero romanesco, além da tendência pós-moderna em analisar as relações dialógicas entre história e ficção e, consequentemente, presente, passado e futuro.

Oribela é a protagonista. Ela é uma jovem portuguesa órfã e de nome pouco convencional, com grafia e melodia semelhante aos nomes de origem indígena. Inclusive, no dicionário indígena, encontra-se uma palavra semelhante ao da protagonista: Oriba, adjetivo que significa alegre, feliz, risonho, aprazível. Portanto, uma jovem bela e feliz, estado contrário à real condição de existência da desterrada.

Ela viaja ao Brasil, junto com outras seis jovens, para casar com um dos portugueses que habitam a Colônia, evitando assim que os mesmos vivam em amasio com as mulheres indígenas. Ela resiste à ideia do matrimônio, pois ainda acalenta o desejo de retornar a Portugal, mas ainda assim se casa com o português Francisco de Albuquerque. Ele, a princípio, gosta da esposa e, a seu modo, desprovido de galanteria ou cavalheirismo, procura tornar a vida da jovem mais confortável, mesmo sendo violentamente brutal na consumação carnal do matrimônio. O embrutecimento humano está nos gestos e ações de Francisco, mas também na sua economia de palavras, na sua forma de conceber as relações familiares e comerciais.

Na segunda tentativa de fuga, a portuguesa aproxima-se do mouro Ximeno Dias. Ela, então, a despeito de todas as referências negativas quanto ao estilo de vida dos não cristãos, envolve-se amorosamente com ele. Após ser encontrada pelo marido, descobre estar grávida, condição que gera um estado de desconfiança em Francisco. Por fim, é abandonada pelo marido após o nascimento de uma criança de cabelos vermelhos, tais como os do mouro.

Quanto à estrutura narrativa, o romance está dividido em 10 partes, que mostram o processo de (não)adaptação da protagonista, e das outras seis jovens, ao seu novo modo de vida, desde a chegada ao Brasil até a conscientização de sua condição no novo mundo. Os capítulos são curtos, não ultrapassando uma página, enumerados e, em sua maior parte, 
desenvolvidos em um único parágrafo. As sentenças obedecem muito mais a certa cadência melódica que à pontuação padrão, pois há um jogo musical com palavras do vocabulário quinhentista e indígena. A narrativa é, em sua maior parte, em primeira pessoa; portanto, a Colônia é anunciada através do olhar, dos pensamentos e julgamentos da protagonista. Há pouco diálogo na trama, sempre em discurso indireto. De modo geral, o romance tem a estrutura de um moderno poema em prosa.

Quanto ao discurso, diferente de outros romances de cunho historiográfico da autora, o foco aqui está no sujeito e nas suas contradições e não especificamente nos fatos e fontes históricas. A estrutura e a estética narrativa - aliadas ao discurso - contribuem significativamente no processo de composição da identidade de Oribela e da sociedade que a cerca. Sobre essa sociedade, podem ser observados alguns pontos evidenciados pelo discurso ficcional, como a ênfase na relação de dependência da Colônia para com a Metrópole, além do desejo comum de retornar a esta; a consciência da selvageria das relações no novo mundo; e, por fim, a sensação de inferioridade do colonizado. Essas questões descrevem/narram os sujeitos, mas também a sociedade recém-iniciada.

A narrativa, produzida em fins do século XX, é consciente de sua posição e olhar privilegiados, isto é, convém a ela abordar criticamente o início da história do Brasil. A protagonista, gerada à imagem do século XVI, é ingênua e imatura, e todo seu saber é embasado em estereótipos, mitos e enganos. Entretanto, na nova terra, ela tem a oportunidade de desconstruir enganos e construir novos saberes.

A gênese ficcional da nação moderna é, em síntese, baseada na transgressão, no preconceito e na discriminação, numa pseudoestrutura de classes, no abuso de poder. $\mathrm{Na}$ transgressão porque são portugueses rejeitados, degredados por Portugal que recebem a tarefa de povoar a nova terra. Eis a descrição dessa população dada pela narradora:

Muitos em torno de nós eram degredados, do que se sabia por não terem suas orelhas, cortadas a modo de castigo no reino e para que os conhecêssemos sempre e sempre soubéssemos que não eram como pêssegos. De doer, a vista daqueles desorelhados, [...] livres e leves, sem deles haver medo, sem deles se presumir, sem pasmo ou difamação, [...] como se lhes não houvesse desterro [...]. A feição das gentes cristãs era escura, de ser cozida pelo sol a pele, todos pareciam donos da terra e do nariz, por não estarem aqui o rei nem a rainha nossa mãe. Degredados eram uma gente sem temor nem conhecimento de Deus e que diziam heresias como podia fazer qualquer animal bruto se soubesse falar porque eram homens sem sangue, sem lei, nação, língua, reino, sem terra e servos, o que se via claramente em suas obras, eram praga contagiosa, peçonhenta e em sua habitação [...] iriam bramir de noite com as feras silvestres da sua mesma vil natureza. 
Uns cristãos mastigavam fumo, como se fossem bárbaros de costumes, quase todos num pobríssimo trato de suas pessoas e nos seus vestidos [...]. Escravas amamentavam suas crias, tendo parido filhos que de rosto saíam brancos mas tisnados em brasa, filhos dos cristãos que delas se enamoravam, na solidão destas terras desabafadas (MIRANDA, 1996, p. 26 , grifos meus).

Vale ressaltar que essa é a primeira vez que a jovem órfã vê o povo do novo mundo, e nas suas opiniões estão entranhados os pré-conceitos dos europeus sobre a terra dos brasis. Porém seu olhar a esse respeito, especificamente no caso do europeu, não muda muito ao longo da narrativa. Para ela, os degredados veem o desterro no Brasil como a oportunidade de um desligamento das regras e normas de convivência e de conduta, tratando com descaso e desprezo, inclusive, a religião cristã, porque nesta terra falavam e respondiam por si. E até mesmo os mais cristãos se deixavam levar pela onda de liberdade comum aos trópicos, vivendo como bárbaros ou selvagens, segundo percepção de Oribela. Para Ronaldo Vainfas (2010, p. 57-58), o degredo no Brasil tinha, basicamente, o propósito de povoar a Colônia e limpar a Metrópole. Assim o diz:

E, no afã de povoar a Colônia, Portugal utilizou-se sistematicamente do degredo, importante mecanismo colonizador e, ainda, depurador da própria Metrópole. Dentre os vários crimes que o direito régio penalizava com o degredo para o Brasil, as transgressões morais não foram as menos notáveis: condenados a viver algum tempo ou perpetuamente no Brasil eram os freiráticos, que invadiam mosteiros para arrebatar as esposas de Cristo; os que desonestassem virgens ou viúvas honestas; os que fornicassem com tias, primas e outras parentas; os que violentassem órfãs ou menores sob tutela; os que, vivendo da hospedagem alheia, dormissem com parentas, criadas ou escravas brancas do anfitrião; os que dormissem com mulheres casadas, e as próprias adúlteras, em certas circunstâncias; as amantes de clérigos; os alcoviteiros de freiras, virgens e parentas dentro do quarto grau [...]. Além desses, a legislação previa o degredo para feiticeiros, homicidas e outros que a prática judiciária acrescentaria com o passar do tempo: hereges, bígamos, sodomitas, judaizantes [...]. A política de povoamento da Coroa portuguesa parece, assim, confirmar a função e imagem [de] [...] "lugar de purgação", "purgatório da Metrópole" desde o século XVI.

$\mathrm{Na}$ medida do possível, os jesuítas tentaram diminuir a vinda dos indesejáveis do Reino para a Colônia: que viesse "melhor gente", que "mandassem homens de bem" [...]. No entanto, o que mais suplicaram os inacianos às autoridades metropolitanas foi o envio de mulheres brancas, base para a construção de uma ordem familiar portuguesa na Colônia e garantia de que as índias ficariam a salvo dos pecados (VAINFAS, 2010, p. 57-58, grifos meus).

Ao desembarcar, a jovem Oribela reza aos pés da imagem de Nossa Senhora em uma ermida, diz temer pela sisudez de seus pensamentos e pureza de seu coração e pede proteção contra os mouros, os judeus, luteranos, blasfemos etc., para ser merecedora de um bom 
esposo, mesmo duvidando que houvesse gente boa nesta terra (MIRANDA, 1996, p. 30). E é duvidando da índole do povo que começa a estabelecer suas relações.

Com poucos grupos a jovem poderia relacionar-se, porque é preciso lembrar que o objetivo das órfãs, determinado pela Coroa portuguesa, ao atravessar o oceano era simples, e foi logo esclarecido: levar uma vida caridosa, vivendo na "[...] majestade do matrimônio divino. A fazer filhos abençoados de alvura na pele" (MIRANDA, 1996, p. 73, grifos meus). Portanto, a amizade com não europeus, ou europeus não cristãos, estava fora de cogitação. A esse respeito fora ensinada ainda na Metrópole. Quanto aos mouros, foi prevenida a manter distância, pois eles representavam o mal sobre a terra, a bestialidade humana, a rudeza e brutalidade de animais selvagens (MIRANDA, 1996, p. 31). Quanto aos indígenas, chamados de naturais, aprendeu que não tinham sentimentos nem humanidade, eram como animais - difíceis, mas não impossíveis de serem admoestados na "ciência dos brancos" (MIRANDA, 1996, p. 145).

Insatisfeita com o casamento e sem tarefas a realizar na casa, Oribela desenvolve afeição por uma natural, a jovem Temericô, que fala a língua portuguesa com “[...] a rudeza dos matos e modos de animais silvestres" (MIRANDA, 196, p. 119). A natural ensina a jovem esposa a falar algumas palavras e a cantarolar músicas de origem indígena. Quando indígenas e portugueses travam uma disputa pela posse das terras habitadas por portugueses, Oribela percebe o sofrimento da nova amiga diante da apreensão e morte dos naturais e diz: "[...] Não sabia que brasil sente dor" (MIRANDA, 1996, p. 144). A órfã sofre também ao ver tantos naturais mortos e tantos outros escravizados, "[...] mesmo sabendo não terem almas" (MIRANDA, 1996, p. 145).

A sogra, Dona Branca de Albuquerque - uma senhora que tem a si mesma em alta consideração -, faz advertência à nora, estabelecendo algumas regras, "[...] antes que [Oribela] virasse [...] uma bárbara da selva e [...] [se] metesse a comer de carne humana" (MIRANDA, 1996, p. 127). Em seguida, avisa ao filho do conluio da esposa com as naturais. Francisco, então, a avisa que as naturais são traiçoeiras e que não sentem afeição ou amizade por quem quer que seja (MIRANDA, 1996, p. 131).

Mas outra questão, prática comum na Colônia, é fundamental para a compreensão do processo de formação cultural da nação brasileira: o jogo e o abuso de poder. Como destacado acima, concentra-se no Brasil, no primeiro século de colonização, um grupo bastante diversificado, porém, basicamente, movido por objetivos comuns: são pessoas forçadas a aqui permanecerem, muitas iludidas quanto à realidade do lugar, todas sonhando com o rápido enriquecimento. Ainda semelhante é a forma como elas veem esse território: um lugar 
selvagem, um rito de passagem, ou seja, onde é preciso viver durante algum tempo sob o sol dos trópicos para, enfim, voltar ao conforto das Metrópoles, com dinheiro, honra e distinção.

Nas palavras de uma das órfãs, dona Bernardinha: “[...] Este mundo é um desterro e nós, estrangeiros" (MIRANDA, 1996, 180). Ou ainda como o exemplo da família de Francisco de Albuquerque que, mesmo vivendo em relativo conforto e desfrutando de muitas regalias, diferente de quando vivia na completa marginalidade social em Portugal, não esquece os planos de um retorno glorioso às terras de seu nascimento, porque, ainda que "[...] ali estivessem muito à vontade sendo em tudo senhores absolutos de toda a terra com tudo não se davam por satisfeitos por ser aquilo degredo, não tinham amor pela terra, queriam tornar ao reino" (MIRANDA, 1996, p. 95)

O sistema de estrutura de classes na sociedade colonial favorece tanto a corrupção política e moral quanto o jogo e o abuso do poder. Ele oportuniza que parte da ralé portuguesa reine soberana nos trópicos. Como um acordo silenciosamente firmado, que inclui o dito e o não dito, a "monstrualização" do outro, o estabelecimento de fronteiras, todo um sistema discursivo e funcional é instituído na Colônia. Em terra sem fé, rei ou lei, os portugueses mandam e desmandam. Os indígenas são as primeiras vítimas, suas terras, cultura e liberdade são usurpadas por qualquer um que se considere em posição de superioridade na pirâmide social; são demonizados, desumanizados e monstrualizados para garantir que gerações seguintes continuem a acreditar que o diferente é um monstro; garantia, inclusive, necessária à manutenção do poder centralizador e inquestionável. Com os africanos, asiáticos e demais grupos que professem religiões ou mantenham hábitos culturais diferentes dos europeus acontece processo semelhante.

Segundo Sérgio Bellei (2000), o conceito de "monstruoso" é aplicado, de modo geral, tanto ao humano quanto ao não-humano e significa o híbrido e o deformado. Esse conceito de monstruosidade aplicado ao humano está historicamente ligado ao conceito de fronteira. Portanto, o monstro "[...] é aquela criatura que se encontra na ou além da fronteira, mas está sempre e paradoxalmente próximo e distante do humano, que tem por função delimitar e legitimar" (BELLEI, 2000, p. 11). Um óbvio processo da monstrualização do diferente, delimitando e legitimando o europeu como humano, é realizado no imaginário popular da Colônia ficcional.

Conforme supracitado, a monstrualização do diferente tem como função primeira delimitar as margens do que se considera humano e legitimar uma etnia ou um grupo social. Dado o seu caráter comparativo (por exemplo, o indígena é monstruoso porque o humano é o europeu), esse processo cumpre ainda a função de centralizar poder, de incitar o medo, 
reprimir a aproximação, de acentuar os limites, as fronteiras. Para Bellei (2000), no contexto de exercício do poder, a fronteira não é apenas uma linha divisória, mas o lugar que marca

[...] o desequilíbrio de poder e conhecimento entre o central e o periférico, o superior e o inferior. A fronteira é o lugar de uma (des)valorização no qual o elemento subordinado não pode deixar de sentir ao mesmo tempo o desconforto da angústia da influência e o embaraço do inevitável desejo de copiar e imitar. O momento da marcação da fronteira é sempre também o momento de um exercício de poder em que se encontram, de um lado, o europeu, o norte-americano, o civilizado, e, de outro, o brasileiro, o sul-americano, o subdesenvolvido. Concretizado tal exercício de poder valorativo, localiza-se de um lado da fronteira uma cultura confiante e auto-afirmativa [sic], de outro uma cultura insegura e de olhos voltados para o valor maior (BELLEI, 2000, p. 150, grifos meus).

Uma das formas de marcar a diferença do monstruoso que está do outro lado da fronteira é desenhá-lo como antropófago. De acordo com Bellei (2000, p. 177-178), o conceito de antropofagia está intrinsecamente ligado à ideia de fronteira, e tem sido empregado em vários momentos históricos para estigmatizar determinados grupos humanos. A designação preconceituosamente formulada pode ser vista como mais uma etapa da construção e manutenção das fronteiras. Se os grupos de uma mesma sociedade partilham sistemas culturais semelhantes, a crença de que um deles come carne humana serve para acentuar as diferenças e ascender os demais grupos a um posto de maior significação social.

A Igreja, por meio de sua mensageira - a Contrarreforma -, e apoiada no olhar do colonialismo eurocêntrico, participou ativamente do processo de monstrualização do outro, adicionando ao imaginário popular termos e conceitos religiosos. $\mathrm{O}$ objetivo era causar o horror, despertar o medo. O monstro não cristão é a representação do Demônio, imitá-lo significaria trilhar o caminho para o Inferno, porque, no contexto colonial,

\footnotetext{
Animalização e demonização andaram de braços dados [...] [no] discurso, que, essencialmente jesuítico, se espalharia entre outros religiosos e leigos até bem avançado o século XVIII. Nas dificuldades da catequese, no tardio descobrimento do trópico pelos cristãos, na origem dos índios, em quase tudo se via o demônio, o Inimigo, o "lobo infernal". [...] Repetiu-se à exaustão que os nativos não pronunciavam as letras $\mathrm{F}, \mathrm{L}$ e R por não terem fé, lei e rei, o que, às vezes, significava vê-los como pobres inocentes em estado de anomia, mas para os jesuítas era claro sinal da anarquia diabólica em que viviam. O Inimigo estava em toda a parte e, aos soldados de Cristo, [...] cabia "ler essas marcas" e saber até que ponto o demônio conseguira embaralhá-las (VAINFAS, 2010, p. 46).
}

A Igreja Católica também tinha seus "mecanismos" de manutenção de poder. A Companhia de Jesus é uma organização religiosa, mas principalmente, sobretudo na Colônia, 
estrategicamente política. O modo como os jesuítas viam o indígena contribuía para justificar a forma como o abuso de autoridade prevalecia em quase todos os tipos de relações mantidas na Colônia: no comércio de bens e da fé e também no comércio das uniões por conveniência. Sim, porque o casamento é um negócio nesse lugar, já que quem “[...] vai ao longe casar ou vai enganado ou vai enganar. [...] Para enriquecer, tudo é bem” (MIRANDA, 1996, p. 61). O papel/função das mulheres portuguesas no Brasil era "[...] ajudar nos trabalhos, [...] fecundar, parir, assim como cristãs e guardar todo o cabedal" (MIRANDA, 1996, p. 55).

Avaliadas com atenção, as jovens são novidades cobiçadas, mercadorias necessárias à conservação moral da Colônia e um bem a ser exibido como condição de superioridade, de status social. As jovens são dadas a casar, o dote (preço) é estabelecido em pequenos mimos. Todas elas, uma a uma, têm seus sonhos esmagados, sua liberdade tomada, seu corpo abusado por aqueles que acreditavam que as protegeriam. Na Colônia, marido é essencialmente algoz.

$\mathrm{Na}$ sua investigação dos mitos de fundação da narrativa brasileira, Helena (1993) propõe a hipótese de que essas narrações se articulam em dupla matriz: como "tópico da origem" e como "tópico da rasura da origem". No primeiro caso, a narrativa parte da crença de que "[...] existe uma origem localizável, concreta, para o fundamento da nacionalidade" (HELENA, 1993, p. 83). No segundo, ela põe “[...] em dúvida que a questão da nacionalidade seja melhor discutida no nível das "origens fundadoras"” (HELENA, 1993, p. 83). Esta segunda vertente problematiza a primeira e rasura o próprio conceito de origem e de sua possível simbolização, revelando o quanto de ideológico nele existe.

Ainda segundo a autora, essas duas matrizes, mesmo em romances que procuram implantar um mito fundador, sempre se encontram. Em Desmundo (MIRANDA, 1996) há a alusão aos mitos de fundação que defendem a síntese étnica, mas, ao mesmo tempo, essa ficção trabalha na desconstrução de tal crença. Como afirma Barthes (2009), não existe fixidez na linguagem mítica, ela é constantemente reavaliada, e a ficção pós-moderna opera no sentido de descentralizar tal linguagem, muitas vezes por meio da paródia.

Portanto, trabalhando na mão e na contramão da história, a ficção de Ana Miranda performa uma sociedade brasileira marcadamente classista e patriarcal, em que o apadrinhamento é constantemente usado como moeda de troca. Nela estão o indígena, o africano, o europeu, o asiático e o mestiço (em variantes diversas). Mas, seguindo a hipótese do "tópico de rasura da origem", nesse mito (um neologismo) há descrença, tanto na síntese das três etnias quanto no pacífico encontro entre culturas, ou ainda no respeito à diferença.

Diferente do que acontece no mito de fundação construído em Iracema ([1865] 1989). José de Alencar apresenta a síntese racial (nesse caso, indígena e português) como um 
encontro cultural, religioso e étnico pacífico. Iracema é, ao mesmo tempo, símbolo da terramãe nacional e alegoria da formação cultural brasileira. A criança por ela gerada é a síntese desse cruzamento étnico, religioso e cultural, em que prevalece a cultura e a religião do europeu; Moacir é o símbolo da unidade nacional. Publicado em 1865, para um público burguês, segundo Helena (1993, p. 85), esse romance funciona como “[...] um pacificador dos conflitos instalados, veiculando uma síntese harmoniosa dos contrários, fenômeno distante do panorama brasileiro daquele momento."

Em Desmundo (MIRANDA, 1996) prevalecem as marcações fronteiriças, o mestiço é a letra escarlate desenhada nos limites entre o "eu" e "outro". Descentralizando essa dialética das etnias, o encontro (amoroso, cultural, religioso) se dá entre portugueses, porém um deles não tem o direito de usar tal designação. Oribela é portuguesa por nascimento e por crença, portanto, por direito natural. Ximeno é português por nascimento, mas, antes disso, é cultural e religiosamente mouro (africano), além de suas feições e cor de pele; ele deveria ser português por direito adquirido, mas não é. Ele é, portanto, um mestiço. O fruto dessa união, apesar de nascido na dor, não representa a unidade nacional, mas exatamente a impossibilidade de encontrar - sintetizar - essa unidade.

Iracema, desejando; Oribela, à força. Ambas pagam o preço do pecado original: com a própria vida e com a vida do único filho, respectivamente. Assim como Moacir e a criança de Oribela, Benoni/Benjamim, filho de Raquel, também nasceu da dor. Vejamos:

E partiram de Betel; e havia ainda um pequeno espaço de terra para chegar a Efrata, e teve um filho Raquel e teve trabalho em seu parto.

E aconteceu que, tendo ela trabalhado em seu parto, lhe disse a parteira: Não temas, porque também este filho terás.

$\mathrm{E}$ aconteceu que, saindo-se-lhe a alma (porque morreu), chamou o seu nome Benoni; mas seu pai o chamou Benjamim.

Assim morreu Raquel; e foi sepultada no caminho de Efrata; esta é Belém. E Jacó pôs uma coluna sobre a sua sepultura; esta $e^{e}$ a coluna da sepultura de Raquel até o dia de hoje (GÊNESIS, 1995, p. 41, itálico do texto, negritos meus).

Raquel chamou seu filho de Benoni (filho da minha dor), e Jacó o chamou de Benjamim (filho da mão destra) por ser filho da mulher que mais amou e por quem precisou servir a Labão por sete anos. Como forma de ser ritualmente atualizada, essa história foi preservada através do símbolo sepulcral - a coluna erguida sobre a sepultura de Raquel.

Situação semelhante se dá em Iracema:

[...] sentindo que se lhe rompia o seio, buscou a margem do rio onde crescia o coqueiro. 
Estreitou-se com a haste da palmeira. A dor lacerou suas entranhas; porém logo o choro infantil inundou sua alma de júbilo.

[...]

- Tu és Moacir, o nascido de meu sofrimento. [...]

O doce lábio emudeceu para sempre; o último lampejo despediu-se dos olhos baços. [...]

O camocim, que recebeu o corpo de Iracema, embebido de resinas odoríferas, foi enterrado ao pé do coqueiro, à borda do rio. Martim, quebrou [sic] um ramo de murta, a folha da tristeza, e deitou-o no jazigo de sua esposa. A jandaia pousada no olho da palmeira repetia tristemente:

- Iracema!

Desde então os guerreiros pitiguaras que passavam perto da cabana abandonada e ouviam ressoar a voz plangente da ave amiga, afastavam-se, com a alma cheia de tristeza, do coqueiro onde cantava a jandaia. (ALENCAR, 1989, p. 103-104, 112).

Iracema dá a vida pelo seu filho. A lembrança da virgem dos lábios de mel permaneceria guardada pelo canto da jandaia, ao pé do coqueiro, mas Moacir talvez nunca conheça a cultura, a história da mãe. Suas referências formadoras serão dadas pelo pai, nos moldes da cultura europeia.

Mas com Oribela, o processo é outro: o seu filho lhe é tomado. Essa criança não é a realização de uma vida (como o foi para Raquel), nem a síntese da unidade de uma nação (como foi o nascimento de Moacir), mas o último golpe para a desgraça total da degredada, isto é, ele é a comprovação do delito, do pecado mortal - religioso, étnico e cultural cometido pela órfã com o mouro.

Segundo a narrativa (MIRANDA, 1996, p. 210), Francisco de Albuquerque e a criança (possivelmente, se é que não a matou antes de embarcar) partiram na nau que levava o bispo Sardinha. Contam as crônicas históricas que Pero Fernandes Sardinha (1495-1556), o primeiro bispo do Brasil, é personagem de uma história (os historiadores se dividem por conta da falta de um relato preciso) que envolve naufrágio, morte e até canibalismo.

Em 1551 foi criada pelo Papa Júlio III a diocese da Bahia, onde o bispo Sardinha exerceu o episcopado de 1551 até 1556. Quando, em 1556, ele embarcou em direção a Portugal na nau Nossa Senhora da Ajuda, com uma centena de pessoas, ela naufragou próximo à foz do rio Coruripe, a cerca de 24 quilômetros do rio São Francisco. A maior parte da tripulação e dos passageiros sobreviveu, porém foi aprisionada, morta e devorada por índios caetés.

Se considerado esse detalhe da historiografia brasileira, nessa nau, também, encontraram a morte Francisco e a criança. A Oribela não restou a possibilidade de um recomeço por meio do filho, nem um coqueiro ou coluna que guardassem lembranças suas, apenas o fogo. O primeiro ato da jovem ao perceber que a criança lhe foi tirada é atear fogo à 
casa, às lembranças, ao passado: “[...] devia esquecer tudo no meu passado, ardendo o fogo na madeira ardia também em minha alma, onde se agasalhavam as renembranças" (MIRANDA, 1996, p. 209).

O mito fundacional aqui é um tópico de rasura da origem, conforme definido por Helena (1993). A paródia da virgem/órfã deflorada, arrancada de suas origens (assim o foi, em diferentes proporções, tanto Iracema quanto Oribela), em Desmundo (MIRANDA, 1996), enfatiza a impossibilidade de sínteses, evidencia a violência que permeou as relações culturais, étnicas e religiosas na Colônia. Mas nessa ficção pós-moderna não há o elogio ao vencedor, mesmo porque não há vencedores, todos perdem; não há veneração às culturas superiores, pois todas são, na Colônia, o "pó sob o tapete" da Metrópole. Não há, enfim, a compensação, a solução imaginária que resolva os conflitos, ao contrário, o texto permanece aberto, os conflitos continuam presentes e não serão resolvidos pelo devaneio (in)conclusivo de Oribela: "Todo o meu mundo esvaneceu, estava eu endoidando, dormindo, sonhando? Ouvi o choro de meu filho, virei e na porta, atravessado pelos raios derradeiros do sol, os cabelos em fogo puro, estava o Ximeno com uma trouxa de criança no colo. Hou há" (MIRANDA, 1996, p. 213).

Segundo Barthes (2009, p. 212-223), apesar de parecer paradoxal, o mito não esconde nada. Ele tem a função de deformar, mas não de fazer desaparecer; e sua função específica é transformar um sentido em forma, por isso o autor afirma que o mito é sempre um roubo de linguagem - uma linguagem roubada e restituída, mas é claro que, quando restituída, já não é a mesma de quando roubada. Quando se produz a partir dessa linguagem roubada, esse sistema semiológico duplo naturaliza o mito, impedindo-o de revelar-se ou liquidar-se. Essa é a razão pela qual o mito é vivido como “[...] uma fala inocente: não porque esconda suas intenções, mas porque elas são naturalizadas" (BARTHES, 2009, p. 223).

Em Iracema ([1865] 1989), o mito deforma a realidade, entretanto não a faz desaparecer, como explica Barthes (2009, p. 223). A fala mítica naturaliza a explicação imaginada e, de acordo com Helena (1993), estabelece-se por meio de elementos simbólicos. E, como é próprio do símbolo, ao mesmo tempo em que apresenta a justificativa revela o injustificável. Ou seja, por um lado,

[...] o projeto de Alencar é apresentar a origem da terra brasílica através da ênfase do componente nativista indígena, produzindo o conceito de nacionalidade alicerçado sobre os valores localistas da terra. Por outro, este projeto se revela uma "idéia [sic] fora do lugar", ao legitimar o processo "civilizatório" implantado pelo colonizador. [...] Nome e topos do nacional, Iracema vai marcar, já no Romantismo brasileiro, a problemática trajetória 
do conceito de nacionalidade, revelando que o "rosto" da origem está longe de ser algo uniforme e unificado (HELENA, 1993, p. 86).

E Desmundo (MIRANDA, 1996), dialogando, em certos trechos parodicamente, com Iracema ([1865] 1989), vem comprovando que o rosto da origem é multifacetado. Evidenciando, consequentemente, que a identidade se estabelece nessas lacunas deixadas entre o narrar e o ser narrado (quando se percebe que a história da origem - cultural, identitária - está longe de ser uniforme e única).

A moderna nação brasileira, imaginada como sendo uma comunidade limitada, mas soberana, carrega, desde a sua gênese, questões mal/não resolvidas. Enquanto muitos imaginam e, com certa passividade, alguns aceitam ser esta apenas a nação do futebol, do samba e do carnaval - em suma, da alegria e das festividades -, muitos insistem em retirar de debaixo do tapete questões ainda incômodas, apesar de demasiadamente discutidas atualmente, como o problema da identidade e da gênese/narrativa da nação.

\section{CONSIDERAÇÕES FINAIS}

Imaginar ficcionalmente a nós, brasileiros, como comunidade, uma nação, requer que desenvolvamos uma autoconsciência de nossa formação história. Para tanto, é imprescindível que lembremos, e movamos à superfície, tudo o que a memória historiográfica e literária nos ajudou a esquecer por séculos e séculos. De acordo com o historiador francês Ernest Renan (1997), para que o sentimento de pertença seja uma realidade é preciso que esqueçamos todas as tragédias humanas que serviram de alicerce à nação.

Entretanto, hoje, mais de um século depois das proposições de Renan (1997), nos vemos diante da emergência do debate, justamente, dessas supostas "histórias de família". Percebemos que só podemos nos imaginar uma nação, efetivamente, se promovermos a discussão, se providenciarmos as reparações históricas. Portanto, com tudo o que já aprendemos com os erros históricos, para sentirmos a unidade nacional não podemos esquecer os massacres dos povos indígenas, a brutalidade do processo de escravização, os estupros de mulheres indígenas e africanas, enfim, o alicerce de violências que sedimentaram o que hoje chamamos de nação brasileira.

A ficção pós-moderna, instintivamente questionadora, surge com um dos mecanismos de implosão dos mitos apaziguadores, conformistas, colonialistas e eurocentrados. Ela está na direção que precisamos dar às nossas narrativas: a história é dolorosa, é violenta, mas, por 
meio desse conhecimento, podemos reescrever outra história - uma história de autoconsciência e reparação social e racial.

Desmundo (MIRANDA, 1996), por meio de uma narrativa autoconsciente da história, memória e potencialidades performáticas da estilística romanesca, oferece ao leitor a percepção de que há muitos não ditos, que há muitos silenciamentos, que a narrativa literária é capaz de implodir os mitos que engendram e "esquecem" violências que nossa historiografia e literatura precisam sim lembrar.

\section{REFERÊNCIAS}

ALENCAR, José de. Iracema. São Paulo: Solidez Edições, 1989.

ANDERSON, Benedict. Comunidades imaginadas: reflexões sobre a origem e a difusão do nacionalismo. Tradução Denise Bottmann. São Paulo: Companhia das Letras, 2008.

BARTHES, Roland. Mitologias. Tradução Rita Buongermino et al. 4 ed. Rio de Janeiro: DIFEL, 2009.

BAUMAN, Zygmunt. Identidade: Entrevista a Benedetto Vecchi. Tradução Carlos Alberto Medeiros. Rio de Janeiro: Jorge Zahar, 2005.

BELLEI, Sérgio Luiz Prado. Monstros, índios e canibais: ensaios de crítica literária e cultural. Florianópolis: Insular, 2000.

BHABHA, Homi K. Narrando a nação. In: ROUANET, Maria Helena (Org.). Nacionalidade em questão. Tradução Maria Helena Rouanet et al. Rio de Janeiro: UERJ, 1997. p. 48-59.

. O local da cultura. Tradução Myriam Ávila et al. Belo Horizonte: UFMG, 1998.

CHAUI, Marilena. Brasil - Mito fundador e sociedade autoritária. São Paulo: Fundação Perseu Abramo, 2000.

ÊXODO. In: A Bíblia Sagrada. Tradução João Ferreira de Almeida. Brasília: Sociedade Bíblica do Brasil, 1995. p. 61-114.

GÊNESIS. In: A Bíblia Sagrada. Tradução João Ferreira de Almeida. Brasília: Sociedade Bíblica do Brasil, 1995. p. 1-61.

GUIBERNAU, Maria Montserrat. Nacionalismo: o estado nacional e o nacionalismo no século XX. Tradução Mauro Gama e Cláudia Martinelli Gama. Rio de Janeiro: Jorge Zahar, 1997.

HALL, Stuart. A identidade cultural na pós-modernidade. Tradução Tomaz Tadeu da Silva e Guacira Lopes Louro. 8 ed. Rio de Janeiro: DP\&A, 2003. 
HELENA, Lucia. A narrativa de fundação: Iracema, Macunaíma e Viva o povo brasileiro. Letras: revista do Programa de Pós-Graduação em Letras da Universidade Federal de Santa Maria, Santa Maria, n. 1, p. 80-94, jul./dez. 1993.

HOBSBAWM, Eric J. Nações e nacionalismo desde 1780: programa, mito e realidade. Tradução Maria Celia Paoli e Anna Maria Quirino. Rio de Janeiro: Nova Fronteira, 2011.

HUTCHEON, Linda. Poética do pós-modernismo: história, teoria, ficção. Tradução Ricardo Cruz. Rio de Janeiro: Imago, 1991.

LE GOFF, Jacques. História e memória. Tradução Bernardo Leitão et al. Campinas: Unicamp, 2003.

MIRANDA, Ana. Desmundo. São Paulo: Companhia das Letras, 1996.

RENAN, Ernest. O que é uma nação? In: ROUANET, Maria Helena (Org.). Nacionalidade em questão. Tradução Maria Helena Rouanet et al. Rio de Janeiro: UERJ, 1997. p. 12-43.

SANTOS, Luis Alberto Ferreira Brandão. Nação sob penumbra. Em tese: publicação do Programa de Pós-graduação em Estudos Literários da Universidade Federal de Minas Gerais, Belo Horizonte, v. 1, p. 21-31, dez. 1997.

VAINFAS, Ronaldo. Trópico dos pecados: moral, sexualidade e inquisição no Brasil. Rio de Janeiro: Civilização Brasileira, 2010. 